
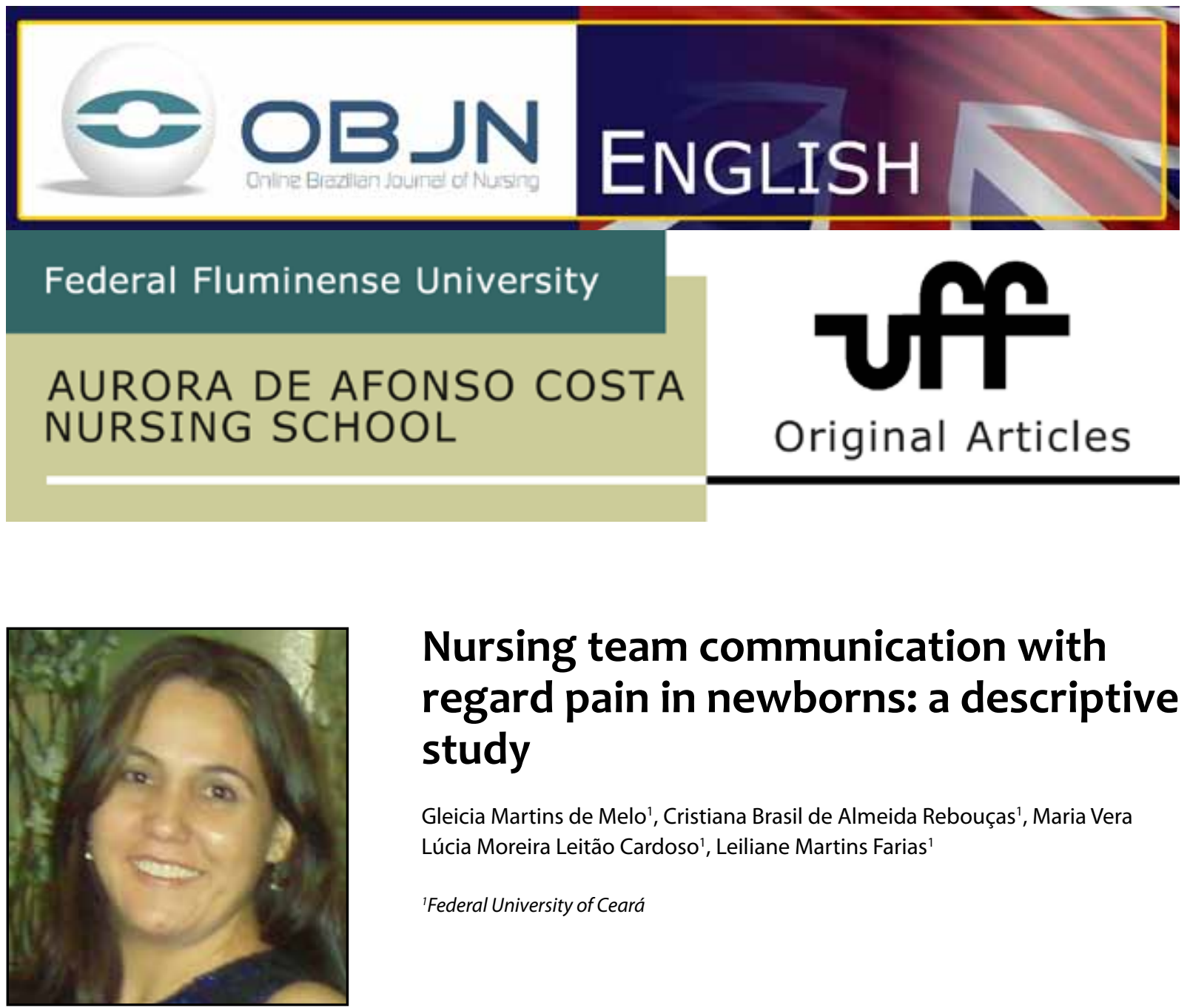

\title{
Nursing team communication with regard pain in newborns: a descriptive study
}

\author{
Gleicia Martins de Melo', Cristiana Brasil de Almeida Rebouças' ${ }^{1}$, Maria Vera \\ Lúcia Moreira Leitão Cardoso', Leiliane Martins Farias' \\ 'Federal University of Ceará
}

\section{ABSTRACT}

Aim: To analyze the verbal and nonverbal communication of nursing professionals with newborns during arterial punctures and calcaneus, from the perspective of health promotion.

Method: A descriptive study, conducted in March 2012, which considered 27 interactions involving nurses and newborns.

Results: data were organized into two themes: verbal communication of nursing professionals before, during and after the painful procedure, and nonverbal communication during the painful procedure according to the Proxemics Theory. Newborns showed professionals expressions of tranquility and crying through nonverbal communication. However, the nurses continued using verbal communication prior to the pain of such procedures.

Conclusion: The nurses investigated established effective verbal or nonverbal communication to newborns. Such an attitude promotes holistic and humane care in the hospital setting, with a focus on health promotion.

Descriptors: Communication; Pain; Nursing; Infant, Newborn; Health Promotion. 


\section{INTRODUCTION}

Communication is present in the daily life of humans and involves the sharing of feelings, beliefs, values and attitudes expressed through messages sent and received by two or more people.

In the hospital context, specifically with nurses, communication is a basic tool in patient care $^{(1)}$. Such communication is expressed verbally or non-verbally to guide, inform, support, comfort and meet the basic health needs of the assisted patients ${ }^{(1-2)}$.

Verbal communication is transmitted through speech, writing, sounds and words ${ }^{(3)}$ and nonverbal communication refers to bodily and facial expressions and touch, among others. Data from a particular study indicated that $7 \%$ of people's thoughts are transmitted through speech, $38 \%$ by their tone of voice, and $55 \%$ by body language ${ }^{(4)}$.

Among the theories of nonverbal communication, this study addressed specifically the Proxemics Theory, with an emphasis on body language and spatial relationships of the individuals involved in the communication ${ }^{(5-6)}$.

Thus, with regard to nurses working in the neonatal unit (NU), recognizing the pain of newborns (NB) during painful procedures, requires maturity, skill and perception. This is because it is a population that communicates through mime and facial expressions, that is, nonverbally.

Taking into account the routine of the unit of the hospital where the research was conducted, it was observed that nurses were responsible for carrying out some painful procedures, including arterial puncture for laboratory exams. Technicians and nursing assistants, in turn, were responsible for heel-lancing using a blood glucose meter.

These procedures are important and essential to therapeutic achievement and preservation of the child's life ${ }^{(7)}$. However, they lead to fear, anxiety, pain, tears and irritation on the part of neonates ${ }^{(8)}$. Given this, it is important that the nursing staff is prepared, insightful, trained, and can communicate effectively with the NB and recognizes the pain that is being experienced by the NB.

From the perspective of communication between nurses and NB when it comes to implementing personalized and holistic nursing care $^{(2)}$ focused on the minimization of pain, we attempted to introduce health promotion measures in order to humanize care, since this is a set of ethical values involving such aspects as life, solidarity, fairness and citizenship ${ }^{(9)}$.

In this context, the interest in evaluating communication on the part of nursing professionals as a strategy for health promotion in response to the pain of the NB has emerged. Thus, the following question was raised: from the perspective of health promotion, how can we develop verbal and nonverbal communication on the part of nursing professionals prior to painful procedures on neonates admitted to the UN?

Thus, this study aimed to analyze the verbal and nonverbal communication of nurses with NB during arterial puncture and calcaneus, from the perspective of health promotion.

\section{METHOD}

This is an exploratory and descriptive study, developed in the NU of a public hospital in Fortaleza, Ceará, in March 2012.

The sample consisted of 27 nurses, corresponding to approximately $30 \%$ of the team that included nurses, technicians and assistants, and $27 \mathrm{NB}$ admitted to the unit studied. The research included the nurses who were on duty at the time of blood collection from NBs for examination and blood calcaneus for glucose levels. We selected the newborns requiring arterial punc- 
ture and calcaneus during the hospitalization period, regardless of diagnosis, gestational age (GA) and length of hospital stay. The NBs and nurses participated in the survey only once, which did not happen intentionally. Therefore, there was a coincidence in the number of subjects.

Data collection was performed with the aid of a form which aimed to characterize nursing professionals through information regarding their professional category, the service time at the NU, and the courses they attended in the field of neonatology. The data related to NBs, in turn, were collected using information extracted from medical records, such as birth condition, gestational age, Apgar score, weight, gender, diagnostic hypothesis and the technique of non-participant observation. The observed data were not disclosed in advance to the professional staff of the unit, to avoid interference in the behavior of nurses.

To capture the communicative process of nursing, nurses were observed while performing the arterial puncture, and technicians and nursing assistants in the execution of the heel-lancing in both daytime and nighttime periods. At this point, we used an observational script developed by the authors to evaluate the verbal communication (speech) of the professional toward the NBs, before, during and after the painful procedure. The professionals were observed throughout the period from the preparation of the material to be used in the procedure at the time of puncture, until the stabilization of physiological parameters. The data relating to verbal communication were analyzed from the speech, based on content analysis, and were found to consist of three stages: organization and systematization of ideas, material exploration, and treatment of the results, inference and interpretation $^{(10)}$.

Another structured script that had been previously validated was used to assess nonver- bal communication. This covered six of the eight proxemic factors proposed by Proxemics Theory: posture and sex, axis sociófugo and sociópeto, kinesthetic factors, contact behavior, visual code and voice volume ${ }^{(11)}$. The thermal and olfactory codes were not analyzed since there were no technical and methodological parameters available to evaluate them ${ }^{(6)}$.

The data obtained on the description of the subjects were presented descriptively to characterize the study participants regarding information concerning the observation of verbal and nonverbal communication on the part of nursing professionals before, during and after the painful procedure towards the NB

The following themes have emerged from the responses of the nurses: verbal communication on the part of the nursing professional before, during and after the painful procedure, and nonverbal communication during the painful procedure. The data were organized in the form of a picture and tables, and were analyzed based on literature pertaining to the subject.

The research was approved by the Ethics Committee in Research of the institution under study, according to opinion No. 020602/11, respecting the ethical principles of research involving human beings. The Instrument of Consent was applied to both nursing professionals and for the parents of newborns selected for arterial and calcaneus puncture before being observed. To preserve the anonymity of the professionals, the letters $\mathrm{N}, \mathrm{T}$ and $\mathrm{A}$, concerning the terms nurses, technicians and nursing assistants were assigned, followed by rising ordinal numbers.

\section{RESULTS}

Of the 27 nursing professionals participating in this study, fifteen were nurses, nine were technicians and three were nursing assistants; all 
female. The average time employed in the NU was one and a half years. With respect to courses in neonatology, the participants had at least one 40-hour course.

Regarding the characterization of newborns admitted to the $\mathrm{NU}$, nineteen were male and eight were female, 26 classified as "preterm" and one "fixed- term."With regard to Apgar scores, there was a variation of 1 to 10 in the 5 th minute of life. The weight of the newborns ranged from $885 \mathrm{~g}$ to $3.982 \mathrm{~g}$. The most frequent medical diagnosis was Respiratory Distress Syndrome (RDS) associated with prematurity.

In assessing the verbal communication of nursing professionals before, during and after the painful procedure, it was found that the nurses were the ones who communicated verbally with the NB most frequently, as shown in Table 1.

Table 1 - Nurses verbal communication toward newborns, before, during and after the painful procedure. Fortaleza, CE, Brazil, 2012

\begin{tabular}{lccc}
\hline $\begin{array}{c}\text { Verbal } \\
\begin{array}{c}\text { comunica- } \\
\text { tion }\end{array}\end{array}$ & $\begin{array}{c}\text { Nurses } \\
(\mathbf{n}=15)\end{array}$ & $\begin{array}{c}\text { Técnicas } \\
\text { de enfer- } \\
\text { magem } \\
(\mathbf{n}=9)\end{array}$ & $\begin{array}{c}\text { Auxiliares } \\
\text { de enfer- } \\
\text { magem } \\
(\mathbf{n}=3)\end{array}$ \\
\hline $\begin{array}{l}\mathbf{N}(\%) \\
\mathbf{N}(\%)\end{array}$ & $\mathbf{N}(\%)$ \\
\hline $\begin{array}{l}\text { Before the } \\
\text { procedure }\end{array}$ & $4(27)$ & $2(22,2)$ & - \\
$\begin{array}{l}\text { During the } \\
\text { procedure } \\
\text { After the }\end{array}$ & $5(33,3)$ & $2(22,2)$ & - \\
procedure & $8(53,3)$ & & - \\
\hline
\end{tabular}

Source: prepared by the authors, 2012

*Different responses from the $n$ of the participants.l

When observing the verbal communication of the nursing professionals with newborns before, during and after the painful procedures of arterial and calcaneus punctures, we sought to record the statements of the participants in Table 1.
Picture 1 - Presentation of nursing professionals' statements toward the newborns before, during and after the procedure painful. Fortaleza, CE, Brazil, 2012

\begin{tabular}{|l|l|l|}
\hline \multicolumn{1}{|c|}{ Before } & \multicolumn{1}{c|}{ During } & \multicolumn{1}{c|}{ After } \\
\hline $\begin{array}{l}\text { I'll stick my } \\
\text { baby, but he will } \\
\text { not cry. (E6) }\end{array}$ & $\begin{array}{l}\text { Don't cry. It } \\
\text { didn't hurt. (E4) }\end{array}$ & $\begin{array}{l}\text { It didn't hurt. My } \\
\text { beautiful baby. } \\
\text { (E4, E6) }\end{array}$ \\
\hline $\begin{array}{l}\text { Oh, my God, I } \\
\text { am such a big } \\
\text { guy. (E7) }\end{array}$ & $\begin{array}{l}\text { Wait, sweety. } \\
\text { (E2) }\end{array}$ & $\begin{array}{l}\text { There, there. It's } \\
\text { over now (E3, E5, } \\
\text { E7, E11, E13, E14) }\end{array}$ \\
\hline $\begin{array}{l}\text { Um, won't hurt } \\
\text { at all. (E11) }\end{array}$ & $\begin{array}{l}\text { There, there, } \\
\text { sweety. (E1) }\end{array}$ & \\
\hline $\begin{array}{l}\text { Hey, little baby, } \\
\text { wake up.(E12) }\end{array}$ & $\begin{array}{l}\text { Oh, dear, you } \\
\text { are so tough, } \\
\text { sorry. (E9) }\end{array}$ & \\
\hline $\begin{array}{l}\text { My baby is so } \\
\text { cute (T2) }\end{array}$ & $\begin{array}{l}\text { It's already over. } \\
\text { (E11) }\end{array}$ & \\
\hline $\begin{array}{l}\text { I'll stick your } \\
\text { foot, but it will } \\
\text { not hurt. (T3) }\end{array}$ & $\begin{array}{l}\text { Alright, alright. } \\
\text { (T1) }\end{array}$ & $\begin{array}{l}\text { I didn't even } \\
\text { cry because my } \\
\text { aunt just sli- } \\
\text { ghtely touches } \\
\text { me. (T8) }\end{array}$ \\
\hline
\end{tabular}

Source: prepared by the authors, 2012

Next, in Table 2, the non-verbal communication of nursing professionals toward the NB is illustrated, according to the proxemics communication.

Table 2 - Proxemic Communication of Nursing professionals toward newborns during painful procedures. Fortaleza, CE, Brazil, 2012

\begin{tabular}{|c|c|c|c|}
\hline $\begin{array}{c}\text { Proxemic } \\
\text { Communication }\end{array}$ & $\begin{array}{l}\text { Nurses } \\
(n=15)\end{array}$ & $\begin{array}{c}\text { Nursing } \\
\text { tech- } \\
\text { niques } \\
(n=9)\end{array}$ & $\begin{array}{c}\text { Nursing } \\
\text { assis- } \\
\text { tants } \\
(n=3)\end{array}$ \\
\hline & N (\%) & N (\%) & N (\%) \\
\hline \multicolumn{4}{|c|}{ 1. Posture and gender } \\
\hline Foot & $15(100)$ & $9(100)$ & $3(100)$ \\
\hline Lying Down & - & - & - \\
\hline \multicolumn{4}{|c|}{ 2. Sociófugo-Sociópeto } \\
\hline Side & $14(93,3)$ & $9(100)$ & $3(100)$ \\
\hline Face to face & $1(6,7)$ & - & - \\
\hline \multicolumn{4}{|l|}{ 3. Distance } \\
\hline Close & $15(100)$ & $9(100)$ & $3(100)$ \\
\hline
\end{tabular}




\begin{tabular}{lccc}
\hline 4. Facial Expression & & & \\
\hline $\begin{array}{l}\text { Tranquility } \\
\text { Smile }\end{array}$ & $11(73,3)$ & $9(100)$ & $3(100)$ \\
\hline 5. Contact behavior & & & - \\
\hline Local touch & $13(86,7)$ & $8(88,9)$ & $3(100)$ \\
Caress & $2(13,3)$ & $1(11,1)$ & - \\
\hline 6. Visual code & & & \\
\hline The professional fully & $9(60)$ & $9(100)$ & $3(100)$ \\
observes the NB & & & \\
The professional stares & $6(40)$ & - & - \\
at the procedure & & & - \\
\hline 7. Voice volume & & - & - \\
\hline Low & $6(40)$ & - & - \\
Normal & $9(60)$ & $5(55,6)$ & - \\
Silence & - & $4(44,4)$ & $3(100)$ \\
\hline
\end{tabular}

Source: prepared by the authors, 2012

Table 3 contains the facial expression of the $\mathrm{NB}$, according to the proxemics communication.

Table 3 - Newborn Proxemic Communication in during painful procedures. Fortaleza, $C E$, Brazil, 2012

\begin{tabular}{lc}
\hline $\begin{array}{c}\text { Proxemic } \\
\text { Communication }\end{array}$ & Newborns ( $\mathbf{n = 2 7 )}$ \\
\hline \multicolumn{1}{c}{ Facial Expression } & $\mathbf{N}(\%)$ \\
\hline Tranquillity & $16(59,2)$ \\
Cry & $11(40,8)$ \\
\hline
\end{tabular}

Source: prepared by the authors, 2012

\section{DISCUSSION}

Communication, when used by nursing professionals, allows the development of the ability to perceive implicit or explicit messages. Therefore, this study demonstrated the need for using communication techniques as a tool that enables the transmission of messages between nursing professionals and patients. Communication is an interpersonal process that involves the verbal and nonverbal exchange of ideas, information and emotions ${ }^{(2)}$.

Without communication, there is no quality in nursing care. With this in mind, we seek to humanize the care of hospitalized children through these professionals, in order to minimize their traumas of hospitalization ${ }^{(12)}$. In this particular study, we realized the need to improve the approach used by technicians and especially nursing assistants in terms of communicating with newborns.

Through the comments of the participating professionals we perceived their concern to avoid pain, to soothe and nurture the newborn as a form of affection. It is important for health professionals to focus on preserving newborns in situations involving painful experiences ${ }^{(12)}$.

During the arterial and calcaneus punctures, the needle insertion represents a painful moment. The nurses and technicians surveyed felt guilty for causing pain in newborns, therefore they tried verbal communication with them. In Pediatric Intensive Care Units (PICU) numerous attempts to draw blood from children are necessary, thus, making hospitalization stressful for patients and their families, and especially for professionals ${ }^{(7)}$.

After the withdrawal of the needle, nurses paid attention to the normalization of physiological and behavioral parameters. By the lines of the professionals, due to the weeping of the NB, care and concern were demonstrated, culminating in verbal communication. Among the parameters of pain, most often cited by nursing professionals, we highlight the facial expression and crying ${ }^{(13)}$.

As the data revealed, $40.8 \%$ of infants showed a crying facial expression during arterial or calcaneus puncture. This demonstrated their discomfort with regard to undergoing painful procedures. The discomfort of neonates led to effective verbal communication between professionals and newborns, as a way to promote nurturing in order to minimize pain and thus promote health. Therefore, the NB communicates pain through crying ${ }^{(13)}$.

However, crying still deserves attention, and worries nursing professionals. It is consi- 
dered a behavioral, dynamic and graduate sign with typical and peculiar characteristics ${ }^{(13-14)}$, which can be interpreted in various ways by caregivers, as ways of determining the amount of attention needed.

It was noticed in the comments of the nursing professionals, that there was concern in avoiding pain on the part of newborns, in completing the procedure, in provide relief and in demonstrating that it did not hurt. In fact, based on the testimonies of the nurses and the technicians, there was a concern to humanize care. Therefore, there is the need for training and courses, as well as in-depth studies, on pain scales for newborns.

The scale is a type of instrument that confirms the presence or absence of pain in newborns through facial signs, physiological parameters and the presence or absence of crying. These tools facilitate the interaction and communication of professionals, who start to pay attention and perceive the evolution of pain in patients, and check the responses of those regarding the therapy used ${ }^{(13)}$.

The most studied types of scales are the Facial Activity Coding System (FACS), the Pain Assessment Scale (PAS) and the Premature Infant Pain Profile (PIPP) ${ }^{(15)}$. In a study of the extent of knowledge on the part of nursing professionals with regard to the pain of NBs, the following results were obtained: $93 \%$ recognize the existence of pain through behavioral changes, while $7 \%$ recognize it through behavioral and physiological parameters ${ }^{(13)}$.

The analysis of nonverbal communication in this study was based on Proxemics Theory. As noted in the data in Table 2, the first factor observed was posture and sex. This factor concerns the basic position of the speakers, as well as the gender of the people involved in the communication, and their influence on behavior. Gender is one of the factors that interferes in the selected distance during interactions ${ }^{(11)}$. As for the sex of the newborn, there was variation, and this result was similar to that found in another study on the subject ${ }^{(6)}$.

In this study, with regard to the posture of the nurses, it was noticed that they were standing and the newborns lying down. We observe the influence of the members of the nursing team, as we consider this fact related to technical professional situations in the neonatal scenario. This is because this attitude is pretty much a standard one because, in order for the professional to able to perform the painful procedure, she needs to stand up, with the NB lying in an incubator ${ }^{(6)}$.

The study of the analysis of Proxemics Communication that addressed the interaction of mothers and hospitalized infants observed that the positions of mothers varied between sitting and lying down ${ }^{(16)}$. The variations in posture did not occur with the nurses studied because they probably represented professionals undertaking systematic care. The newborns, on the other hand, remain exclusively in the lying position, as they are predominantly kept in heated incubators $(\mathrm{HI})$, radiant heat cradles $(\mathrm{RHC})$ or common cradles $^{(16)}$.

The sociófugo and sociópeto factors refer to the degree of intimacy of the professionals in relation to the NB. Sociópeto demonstrates encouraging interpersonal relationship while sociófugo shows discouragement ${ }^{(11)}$. We observed in this study the presence of lateral angle and face to face connections. In this axis, the lateral angle prevailed in $93.3 \%$ of the nurses and in $100 \%$ of the technicians and nursing assistants. This was due to the fact that most NBs were in $\mathrm{HI}$, and it is necessary for the professional to remain lateralized during the procedure. The face to face angle was seen in $6.7 \%$ of nurses. This is due to the fact that the NBs are in an RHC. Thus, the position is easier when performing painful 
procedures. Therefore, the professionals have demonstrated encouragement in the communication with respect to the axis.

When providing care to newborns, there is a predominance of the lateral position and face to face, in the bath and during diaper change ${ }^{(17)}$. The back angle was not observed, because, in order for the professional to look and perform the painful procedure, she must approach the NB angle face to face or laterally.

An intimate distance prevailed among professionals. The distance is directly influenced by care time ${ }^{(18)}$. Therefore, the findings of this study are justified by the fact that nurses maintained direct contact with the NBs, since they touched them during procedures and while providing assistance, thus corroborating data from another study $^{(19)}$.

It was also found, by means of the facial expressions of the professionals, that a calming demeanor prevailed on the part of the technicians and the nursing assistants; for $73.3 \%$ of nurses and; for $26.7 \%$ a smile was present. This signals the preparation of these professionals when assisting NBs during painful procedures.

Regarding contact behavior, we observed the ways in which the professionals touched the NBs. The tactile relationships observed were in the form of local touches and caresses: $86 \%$ of nurses, $88.9 \%$ of technicians and $100 \%$ of nursing assistants performed local touches, and $13.3 \%$ of nurses and $1.1 \%$ of technicians caressed the NBs. The touch involves an affective aspect and its characteristics are related to the place where they touch, to the time spent in contact, and the pressure exerted by that touch in the body $^{(20)}$.

The local touch was the clearest evidence for the fact that, during the process of arterial and calcaneus puncture, it is necessary for the professional to touch the location that will be affected. The caress demonstrates humanization and concern on the part of nursing professionals with regard to avoiding giving pain to the NBs.

Regarding the visual code of the study, $100 \%$ of the technicians and nursing assistants and $60 \%$ of the nurses carefully looked at the NB during the painful procedure, and $40 \%$ of them fixed their gaze on the site of the procedure. The findings showed that during the painful procedure the nursing professionals were attentive to the behavioral and physiological reactions of the NBs. At this time, the professionals tried to soothe and entertain, thereby promoting a more positive reaction. Thus, there was an agreement between what was said in terms of the verbal communication of the professionals and what was observed in the visual code.

The visual code is the one that occurs in the form of eye-to-eye contact. This type of contact was partly observed in another study involving mother and child ${ }^{(16)}$.

It was observed that $60 \%$ of nurses and $55.6 \%$ of nursing technicians kept their voice volume appropriate to the NBs when performing painful procedures; $40 \%$ of nurses lowered their voice volume, $44.4 \%$ of the technicians and $100 \%$ of the nursing assistants said nothing during the painful procedure. According to the findings, we identified the concern of professionals when assisting the NBs, in terms of not raising the volume of their voices. This fact has demonstrated caution and concern on the part of the team, since the NU is a noisy environment, a characteristic that tends to evoke an increase in voice volume. The findings corroborate results from another study performed with NBs, children and mothers with visual impairment ${ }^{(5)}$.

\section{CONCLUSION}

In order to promote a humanized and holistic assistance in a health promotion scenario 
in the hospital, as exposed by this study we confirm the importance of nursing professionals in maintaining effective verbal and nonverbal communication before, during or after painful procedures involving NBs. It was observed that nurses were more aware of the need for effective communication with the NBs, while the technicians and nursing assistants were not very effective in terms of this process. Therefore, we emphasize the importance of the nurse's role as a health promoter within the team, when emphasizing the verbal and nonverbal communication with newborns.

The concern with the newborns on the part of the nursing professionals was observed. This caused satisfaction regarding humanization and health promotion in the care of the newborn. It is noteworthy that when the newborns maintained nonverbal communication, either through physiological or behavioral parameters or by crying, the professionals were attentive to their answers. Thus, we perceive the importance of teamwork, in which professionals understand and broaden the vision of health promotion.

Thus, the results of this study may encourage more nursing professionals to communicate effectively when assisting newborns, in order to promote better pain-coping strategies during hospitalization, by means of effective humanization which may improve the quality of life in the NU.

\section{REFERENCES}

1. Pontes AC, Leitão IMTA, Ramos IC. Comunicação terapêutica em Enfermagem: instrumento essencial do cuidado. Rev bras enferm. 2008; 61(3):312-8.

2. Rodrigues MVC, Ferreira ED, Menezes TMO. Comunicação da enfermeira com pacientes portadores de câncer fora de possibilidade de cura. Rev enferm UERJ. 2010; 18(1): 86-91.
3. Santos CCV, Shiratori K. comunicación no verbal: su importancia en los cuidados de enfermería. Enferm glob [Internet]. 2008 [cited 2012 Apr 20]; 7 (11): [about 9 p.]. Available from: http://revistas. um.es/eglobal/article/view/912/912

4. Silva MJP. Comunicação tem remédio: a comunicação nas relações interpessoais em saúde. São Paulo: Loyola; 2006.

5. Wanderley LD, Barbosa GOL, Pagliuca LMF, Oliveira PMP, Almeida PC, Rebouças CBA. Comunicação verbal e não verbal de mãe cega durante a higiene corporal da criança. Rev RENE. 2010; 11 (n. ${ }^{\circ}$ esp.):150-9.

6. Farias LM, Cardoso MVLML, Oliveira MMC, Melo GM, Almeida LS. Comunicação proxêmica entre a equipe de enfermagem e o recém-nascido na unidade neonatal. Rev RENE. 2010; 11(2):37-43.

7. Ferreira $M$, Chaves $E$, Farias L, Dodt R, Almeida $P$, Vasconcelos $S$. Care of nursing team to children with peripheral venous puncture: descriptive study. Online braz j nurs [Internet]. 2012 [Cited 2012 May 14]; 11 (1): 79-89. Available from: http:// www.objnursing.uff.br/index.php/nursing/article/view/3558

8. Morete MC. Avaliação da dor do escolar diante da punção venosa periférica. Rev dor. 2010; 11(2):145-9.

9. Oliveira MMC, Barbosa AL, Galvão, MTG, Cardoso MVLML. Tecnologia, ambiente e interações na promoção da saúde ao recém-nascido e sua família. Rev RENE. 2009; 10 (3): 44-52.

10. Bardin L. Análise de conteúdo. 4. ed. Lisboa: Edições 70; 2008.

11. Hall ET. A dimensão oculta. Lisboa: Relógio D`Água; 1986.

12. Presbytero R, Costa MLVC, Santos RCS. Os enfermeiros da Unidade Neonatal frente ao recém-nascido com dor. Rev RENE. 2010; 11 (1):125-32.

13. Crescêncio EP, Zanelato $S$, Leventhal LC. Avaliação e alívio de dor no recém-nascido. Rev eletr enf [Internet]. 2009 [cited 2012 Apr 20]; 11 (1): 64-9. Available from: www.fen.ufg.br/revista/v11/n1/ pdf/v11n1a08.pdf

14. Branco A, Fekete SMW, Rugolo LMSS. O choro como forma de comunicação de dor do recém-nascido: uma revisão. Rev paul pediatria. 2006; 24 (3):270-4. 
15. Guinsburg R. A Linguagem da Dor no Recém-Nascido [article in the Internet]. [cited 2012 May 20]. Available from: www.sbp.com.br/pdfs/ doc_linguagem-da-dor-out2010.pdf

16. Vasconcelos SG, Paiva SS, Galvão MTG. Comunicação proxêmica entre mãe e filho em alojamento conjunto. Rev enferm UERJ. 2006; 14 (1):37-41.

17. Galvão MTG, Lima ICV, Aguiar LFP, Pedrosa NL. Comunicação entre mãe hiv+ e filho à luz da tacêsica em ambiente natural e experimental. Esc Anna Nery. 2012; 16 (1):163- 71.

18. Paiva SS, Galvão MTG, Pagliuca LMF, Almeida, PC. Comunicação não-verbal durante cuidados prestados aos filhos por mães com Vírus da Imu- nodeficiência Humana. Acta paul enferm. 2010; 23 (1):108-13.

19. Rebouças CBA, Pagliuca LMF, Sawada NO, Almeida PC. Validation of a non-verbal communication protocol for nursing consultations with blind people. Rev RENE. 2012; 13 (1):125-39.

20. Azevedo AL, Araújo STC. Tocando o corpo e sentindo a vida: leituras não-verbais do paciente em coma à tacêsica pela enfermagem. $R$ pesq cuid fundam. 2010; 2 Suppl:220-3.

Received: $19 / 08 / 2012$

Received: 15/05/2013

Approved: 09/08/2013 